\title{
When borders lie within: ethnic marriages and illegality on the Sino-Vietnamese border
}

\author{
Elena Barabantseva ${ }^{1}$ \\ Accepted for publication in \\ International Political Sociology
}

\begin{abstract}
This article examines the changing geopolitical realities, which redefine the nature of sovereign governance on the Sino-Vietnamese border. The binary forms of classification in a rigidly and clearly delimited Sino-Vietnamese borderland replace the ambiguous space of 'zomia' with its fluid and overlapping identifications. This dynamic context sets the conditions for local communities and their long-standing tradition of ethnic marriages straddling the borders of China and its neighbouring states. In order to understand how and why the status of the earlier accepted forms of undocumented ethnic marriages has recently changed from 'common' (shishi) to 'illegal' (feifa) in two ethnic Yao villages, I look at how state discourses on marriage migration in Asia, biopolitical concerns about population security in China and regional iterations of the global anti-human trafficking campaign come into play in forceful ways to shape the geopolitical regime of the Sino-Vietnamese borderland, redefine the terms of legitimate practices, thus reconfiguring ethnic marriages as illegal.
\end{abstract}

Key words: Sino-Vietnamese border, zomia, ethnicity, marriage, illegality

\section{Introduction}

The majority of marriages in the rural mountainous areas between China and its Southeast neighbours (Vietnam, Myanmar, Laos) continue to take place within the ethnic community networks straddling state borders, defying the competing geopolitics of states, their citizenship regimes, and immigration regulations. Like in other parts of the world, residents in this border area share closer links with people across the border than with their co-nationals (Wilson and Donnan 1998). A long-standing practice among the ethnically

\footnotetext{
${ }^{1}$ Elena Barabantseva is Lecturer in Chinese International Relations at the University of Manchester. She has published on various manifestations of Chinese nationalism, including Chinese diaspora politics, ethnic policies, and state development projects. Her book exploring the role of Overseas Chinese and ethnic minorities in Chinese national project was published by Routledge in 2010. Her articles appeared in Critical Asian Studies, Alternatives, Modern China, Journal of Contemporary China, and other scholarly outlets.
} 
related people, cross-border ethnic marriages have been regarded by the state as customary practices and tolerated, but in recent years became increasingly problematized as illegal. This article examines this change in the context of transforming geopolitical realities, which redefine the nature of sovereign governance on the Sino-Vietnamese border. I show how the binary forms of classification replace the ambiguous space of 'zomia' with its fluid and overlapping identifications. Amidst this transformation, the conceptualisation of what counts as a legal and illegal marriage becomes more rigid. The discussion in this article illustrates how bordering processes at three intersecting levels contribute to reorganising human relations on the terms of state sovereignty.

In order to understand how and why the status of the earlier accepted forms of undocumented ethnic marriages has changed, I look at how state discourses on marriage migration in East Asia, state concerns about immigration and population security in China and regional iterations of the global anti-human trafficking campaign come into play in forceful ways to shape the geopolitical regime of the Sino-Vietnamese borderland. I argue that the changing status of ethnic marriages from 'common' (shishi) to 'illegal' (feifa) highlights how the delimitation of sovereign space and promotion of the border as an absolute and natural line marking sovereign territory, national imaginary, and citizenship rights lays the foundations for illegality for those who ambiguously relate to the rigidly defined state borders.

The entry point for my analysis of the state, regional, and global processes shaping the meaning of the border was the collaborative field research with the Guangxi University for Nationalities which took place in two ethnic Yao settlements on the border of Vietnam's Lang Sơn province and China's Guangxi Zhuang Autonomous region in April 2012 and April 2014. I give a fuller ethnographic account and tensions on the ground elsewhere (forthcoming). The main concern of this article is to chart out how the local changes are linked to the broader processes and discourses. The fieldwork was supplemented by the interviews with Chinese academics and state representatives, and the analysis of local media coverage and Chinese scholarship on ethnic relations in the area.

The first section introduces the distinction between 'zomia' and borderland to set the context for the recent transformations on the Sino-Vietnamese border, which increasingly erase room for legitimate non-state sovereign expressions. The second section traces the 
recent official redefinition of ethnic marriage practices as 'illegal' in our fieldwork site and along China's border with Vietnam more generally. The third section looks to the effects of the regional discourses on marriage migration and 'foreign brides' in Southeast and East Asia on the shift in the official language and attitude towards cross-border marriages in China. The fourth section considers the implications of China's domestic debates on immigration and population security for the illegalisation of ethnic marriage practices in the border areas. The fifth section discusses how the formulation of the anti-human trafficking regime in the Southeast Asia contributes to the production of illegality of undocumented ethnic marriages. Conclusion recaps the argument maintaining that the discursive processes at the three interweaving levels contribute to the promotion of the binary view of the border. This new geopolitical reality limits the official perspective on the people who ambiguously relate to the rigidly defined state borders to the legal/illegal spectrum.

\section{Between 'Zomia' and 'Borderland'}

A popular argument in the recent IR scholarship maintains that the dominant Western geopolitical knowledge developed as a result of colonial conquests where a particular version of history and geopolitical knowledge won (Agnew 2007, Mignolo 2011). This urge to problematise the foundational origins of the discipline gave rise to the growing body of critical studies, including critical border studies. This literature draws attention to state borders possessing both material and symbolic qualities, rather than being preordained rigid lines marking the absolute limits of the state (Deiner and Hagen 2010, Johnson, Jones et al 2011). It calls to interrogate the 'territorial trap' vision of the world, premised on the idea of state sovereignty with its clear separation between domestic and international, and a bounded understanding of societies (Agnew 1994). Borders are conceived of as zones of transition and convergence, where particular border cultures and identities take shape (Flynn 1997, Alvarez 1995, Donnan and Wilson 2010). The debates on 'where the border is' continue, highlighting the effects of the global economy and the advancements in technologies and state surveillance mechanisms, which remove borders from their territorial locations (Vaughan Williams 2008, Johnson, Jones et al 2011). Perhaps the precise location and material expression of the borders matters less than the bordering logic of 'statist and territorial governmentality' which lies at the heart of borders (Soguk 2007: 184). Rather than 
the markers of the 'limits' of the nation-state (Donnan and Wilson 2010: 2), borders are the cornerstone of the idea of state sovereignty where the spatial life of the state emanates from (Reeves 2014). They serve as an entry point to seeing how states formulate and maintain their sovereignty, but also where the idea of absolute state sovereignty breaks down. The dynamics of borders, where security concerns are ingrained into their everyday life (Ferradas 2010), shed light on how state sovereignty, geographies of legality and illegality, intimacy and state security are continuously contested and negotiated.

This article analyses the policy inscriptions of the border and mobility across them as an expression of state sovereignty that impacts on ethnic marriages practices of people living across the Sino-Vietnamese border. Close cross-border links are reflected in the family composition of the two Yao villages where we conducted research. Among 65 households, 55 women (out of 225 population) living there came from the Yao villages on the Vietnamese side of the border. They maintain close links with people from across the border, and the interactions with them during market days, special occasions and fair days constitute an important part of their life. On special occasions a Yao priest from the Vietnamese side of the border comes to perform the Dao rituals. This is a common rather than an exceptional phenomenon along China's Southeast Asian borders. Hundreds of such villages exist and Chinese scholarly publications on cross-border marriages predominantly adopt an individual case study approach to their analyses (Liang and Chen 2014; Li and Long 2008 a,b; Gu 2009). State sovereign logic dominates scholarly accounts of the Sino-Vietnamese border dynamics which aim to understand 'inter-state relations from the perspective of a locality' and consider 'different type of inter-state relations' (Chan 2013: 5, 10). In contrast, the analysis in this article locates border dynamics in the broader context of changing geopolitics of the area where the room for alternative non-state expressions of sovereignty and borders as 'zomia' (see below) is shrinking. With the penetration of the sovereign logic of drawing binary distinctions and its manifestation in the international border and immigration regulatory regime, a new language of illegality takes shape. Ethnic marriages on the Sino-Vietnamese border highlight the oddity and limitations of the system of nation-states, where local people and practices which defy the logic of the mutual exclusivity of citizenship regimes, find themselves in a position of undocumented migrants. However, they did not embark on a journey of migration to find themselves in this situation.

This mountainous area where the East and Southeast Asia meet is part of what James Scott refers to as 'zomia', a nonstate space where 'owing largely to geographical obstacles, 
the state has particular difficulty in establishing and maintaining its authority' (Scott 2009: 13). ${ }^{2}$ The Chinese state and scholars refer to these areas as 'old, remote, scarcely populated, mountainous, and poor' (lao, shao, bian, shan, qiong) (Zhang 2009: 211, Huang and Chen 2011: 83). Scott, on the other hand, argues that the habitat and lifestyle in these areas are akin to the tactics of evading state control and formation (Scott 2009: 9). Sovereign borders, a mechanism of the state to exercise control of the territory and population, does not chime easily with the organisation of social and economic lives of 'zomia' people. Traditionally perceived to be 'outside the history of the Chinese imperial past', the Yao only became incorporated into the Chinese state's language of multi-ethnic nation-state after the establishment of the PRC in 1949 (Litzinger 1995: 117). The Chinese official history talks of the Yao as primitives who for a large part of history moved around the mountains without permanent place of living, and relied on 'slash and burn' subsistence. However, recent interpretations of Yao religious practices and texts reveal that through the adoption of written Chinese script and Daoist practices, the Yao developed a complex socio-philosophical system with a rich written history telling of their special position and exemptions granted by the Chinese Emperor himself (Alberts 2006, ter Haar 1998). The so-called 'Passport for the Crossing of the Mountains' (guo shan bang), copies of which are made and passed on to the next generation in Yao villages across Southeast Asia, attests the right of the Yao to cross and explore the mountains (ter Haar 1998: 13). The origins of this mythical written narrative are uncertain, but they matter less than their impact on how the Yao formulate their worldview as descendants of the privileged outcasts of the Chinese imperial system.

China's borders with Vietnam are a fairly recent and incomplete political project - the unresolved dispute over the maritime space continues to the present day. Like other state borders in East and Southeast Asia, the formalisation of the Sino-Vietnamese border originated in the colonial practices of the European states. The imagination, projection and implementation of the organisation of political life in accordance with the European models manifested in maps and border commissions, provided a blueprint for the non-European colonial contexts (Winichakul 1994). These projects were premised on fixing territorial borders and demanding allegiance to one source of authority at the expense of multiple loyalties, and fluid forms of affiliation which were common in the precolonial period in

\footnotetext{
${ }^{2}$ Giersch (2006) makes a similar point with reference to Yunnan's frontier in the late Qing Empire $\left(18^{\text {th }}-19^{\text {th }}\right.$ centuries). He calls the area the 'middle ground', where the Qing rule was compromised by the practices of local indigenous communities.
} 
Southeast Asia (Toyota 2005: 113). ${ }^{3}$ The fixing of the territorial border laid the ground for the transformation of the people living in these areas into ethnic minorities (Keyes 2002: 1174-1175). After the fall of the colonial rule and formation of the Democratic Republic of Vietnam in 1945 and the People's Republic of China in 1949, the two communist states had unstable relations varying between periods of brotherly support and times of war. In the 1950s both states carried out extensive ethnic minority identification projects with the aim to scientifically determine the ethnic composition of the newly formed socialist states (Keyes 2002: 1181-1187). Following the brutal border war in 1979 and the normalisation of bilateral relations in 1991, a series of negotiation rounds on territorial issues between China and Vietnam resulted in the Border Delimitation Treaty of 1999 with the demarcation of the land border completed in 2009 (CNN 2009). ${ }^{4}$

Throughout the years of imperial and state contest over the territory, the people living in the mountainous areas of Northern Vietnam and South China carried on with their everyday lives. Even during the turbulent years of the 1979 border war, border-crossings over the disputed, fought-over territory did not completely stop. One of the earliest documented scholarly investigations of cross-border marriages in China finds that in one part of the border in the period between 1979 and 1985122 women crossed the border and settled for marriage in China (Liu 1986: 15). In our own survey of forty-nine married women in the two villages, out of five women who came to the villages in the 1970s, four were from the villages on the Vietnamese side of the border, and only one from China. These marriages are an expression of how locals have organized their social and cultural lives, in line with their environmental context, historical, cultural, kinship, and ethnic trends. They do not correspond, and are often in direct tension with state borders, and accepted social and ethnic categories (Zhou 2002: 223-224). For example, the people who in China qualify as the Zhuang ethnic group (the largest ethnicity after the Han), and are identified in Vietnam as Dai or Nong, see themselves as part of wider Budai and Bunong groups and their marriage patterns reflect these ethnic connections (Zhou 2002: 234). Yao is a conglomeration of loosely related ethnolinguistic

\footnotetext{
${ }^{3}$ The origins of the contemporary Sino-Vietnamese border lie in the 1885 Tianjin agreement between France and the Chinese Qing Imperial Court, and the recognition of French domination in Indochina.

${ }^{4}$ After the 1991 bilateral agreement on peace and development in the border area, four international border crossing points were developed: Huunghi-Youyuguan at Lang-Son/Guangxi (April 1992), Dongdang-Pingxiang at Lang Son/Guangxi, Lao Cai-Hekou at Lao Cai/Yunnan (May 1993) and Mongcai-Dongxing at Quang Ninh/Guangxi (April 1994) (Chan 2013: 15).
} 
groups with origins in China and now extending across the Southeast Asia and beyond. In Vietnam they are referred to as Dao or Zao, and in other parts of Southeast Asia as Mien (Sowerwine 2013: 104). Ethnic marriages continue to reflect ethnic patterns and networks connecting people across China's borders with its Southeast Asian neighbours. Although the process of subsuming these areas into the state sovereign logic started in the imperial and colonial periods, it has been in continuous development and recently influenced by the move away from the state practices of national cartography, ethnic categorisation, and classification to state redefinitions of legitimate cross-border mobility.

\section{From 'common' to 'illegal' marriage}

The formalisation and materialisation of the Sino-Vietnamese border is a post-1990s' development. With the liberalisation of the two countries' economies and stabilisation of their relations, economic and trade exchanges between the people accelerated, but so did the state's reach to control who crosses its borders. The 1994 Rules Governing the Implementation of the 1985 Law of the PRC on the Control of Entry and Exit of Aliens provided the first legal framework regulating exit to and departure from China in the postMao period (Zhu and Price 2012: 20). With the introduction of the legal mechanism came the vocabulary of legality and illegality, and the concepts of 'illegal crossings', 'illegal residents', and 'illegal cohabitation', or 'three illegals' (san fei) in short, followed the suit. ${ }^{5}$ This vocabulary set the new framework for understanding the phenomena which long preceded them. The institutionalisation of the bi-national border, alongside citizenship regimes, documentary forms of documentation to register residency and marriage produce similar effects to the post-World War One institutionalisation of the international passport regime which complicated the movement of people who lacked the documentary evidence of their identity and engendered the enduring international question of stateless people and later refugees (Torpey 2000: 127). The case of the undocumented ethnic marriages partners is akin to the situation with stateless persons before the formulation of the international refugee regime when 'no law existed for them'.

\footnotetext{
${ }^{5}$ The concept of 'three illegals' (san fei) entered Chinese official, public, and scholarly discourses in the early to mid-2000s to refer to people who violated China's Entry and Exit Law in relation to the conditions of entry, stay, and work in China alongside the increased number of crack-downs on illegal immigrants (Zhuang 2007). There are slightly different interpretations of this concept, and with reference to cross-border marriages, illegal cohabitation or illegal births are used more frequently than 'illegal work' (Jiang 2012).
} 
Until the 2000 population census and the installation of the border stones in 2001 , the ethnic common marriages were not known about and reported widely outside of their immediate border area. Or, perhaps there was no need to know about them, as it was beneficial to not report them to higher authorities (Andreas 2000). In addition to its historical presence in the area, the Yao ethnic marriage partners from Vietnam started filling in an important gap in the local labour and marriage market, and correcting the skewed local demography. Since the start of the reforms in the late 1970s, China's economic model has been dependent on the low-cost female labour which created a mass movement of floating population to neighbouring Guangdong province. Young women from the countryside sought factory employment for several years prior to marriage and many married elsewhere and never went back to live in their region. This labour migration of rural women has intertwined with the earlier existing marriage practices in this and other areas of China. The two Yao villages consist of two patrilineal lines, and the preferences for exogamy require that marriage entails crossing village borders. As anthropologists have observed, marriage is always 'about borders and boundaries' (Oxfeld 2005: 19), and the normative principles of patrilineality and patrilocality practiced by the majority Han and ethnic minorities in China mean that historically women have been those who crossed the territorial and familial borders to enter their married life with their husband's family. With the outflow of local women the demand for women from Vietnam to fill in the roles in the local society as wives, mothers, and agricultural labour force increased. This movement of local and women from Vietnam created an ensuing problem of 'the out of place bodies' who the government cannot properly control.

There are no official figures of the number of undocumented ethnic marriages in the border areas, and their number is approximated on a case-to-case basis. Chinese scholars estimate that in the early 2000 s 10,000 of such marriages were in place in the SinoVietnamese and Sino-Lao borders (Zhou 2002: 200). A decade later, according to one scholarly study in Guangxi alone, the number of Vietnamese female marriage migrants exceeded 50,000 (Jiang 2012: 120). ${ }^{6}$ When the scale of ethnic marriages in the Chinese

\footnotetext{
${ }^{6}$ These estimations are for the regional and provincials levels in Yunnan and Guangxi. A significant and growing number of studies on cross-border marriages also give an indication of the number of such marriages in the fieldwork sites. For example, Shen found that in Dehong township in Yunnan on the Chinese border with Myanmar out of 6,520 cross-border couples, 1,102 couples or 16.90\% had marriage certificates (Shen 2012). Li and Long estimate that along Sino-Vietnamese the proportion of Sino-Vietnamese marriage varies between ten to fifty per cent ( $\mathrm{Li}$ and Long 2008a: 77). Wang reports that in three border counties in Wenshan prefecture of Yunnan province the number of cross-border marriages doubled from 500 to 1,000 between 2004 and 2006 (Wang 2010: 96).
} 
borders was discovered by the state during China's population census in 2000, the Chinese authorities granted the children, and in certain instances partners of the unregistered marriages a household registration, after the fine for the illegal birth was paid (Zhou 2002: 247). The undocumented ethnic marriage partners were treated as 'actual Chinese citizens' (shishi shang de zhongguo gongmin) who were not seen to cause any social concern or undermine stability in the border area (Li and Long 2008b:78; Zhang 2009:211). From our field research it emerged that until 2007 the local government tolerated the unregistered ethnic marriages in the two Yao villages, and even helped the women who came from Vietnam to apply for the Chinese 'household registration' (hukou) which constitutes the backbone of the biopolitical citizenship and the 'heart of police state' (Torpey 2000: 131) in China $^{7}$. In the early 2000 s there was some drive by the local authorities to explain the purpose of registering marriage to the couples. According to the information provided by the county-level Civil Affairs Bureau (Minzheng ju), between 2010-2012 not a single crossborder marriage was registered there. This concurs with the Chinese scholar's research conducted in this area in the 1990s which found that all registered marriages with a foreigner involved a spouse from distant countries, including the US, France, Japan, while there was not a single registered marriage with a spouse from the neighbouring Vietnam, Laos or Myanmar (Zhou 2002: 224).

By the mid-2000s the state tolerance of undocumented marriages has decreased. The women in the two Yao villages reported that in 2007 the government officials took their earlier issued household registrations away if they said they came from Vietnam. Although a number of scholars emphasise the importance of viewing these marriages as 'common' and propose to find the way of recognising and legalising their status in China (Tan 2012, Du 2014), the predominant trend in academic and policy discourse in China is to interchangeably refer to the undocumented ethnic marriage partners as China's 'three illegals' (san fei renyuan) (Wang 2011: 119-120; Huang and Chen 2011: 85). Outside their family and immediate community, these women are invisible or 'black' people (heiren) in the Chinese governing system, and official statistics. During the $6^{\text {th }}$ national census of 2010 , the

\footnotetext{
${ }^{7}$ Chinese researchers report similar findings. For example, Hou (2012) found that the local authorities in Boshan county on the SinoMyanmar border registered women who came from Myanmar during the 2000 National population census and issued these women with hukou. Gu (2009: 7) reports similar findings in a Dai village on Yunnan. The household registration system or hukou was introduced in 1955 to restrict the movement of population between cities and the countryside. Modelled on the institution of propiska in the Soviet Union, it essentially tied rural population to their life in the countryside preventing their move to the cities where they didn't have residential, work, social and welfare rights.
} 
unregistered marriage partners were not included in official data. ${ }^{8}$ The Ministry of Civil Affairs does not recognise ethnic marriages as valid international or cross-border marriages and does not include any information on such marriages in its statistical publications (Jeffreys and Wang 2013). Instead, a special census of cross-border marriages takes place regularly at the county level, but the data is a 'state secret' and is not disclosed by the Public Security Bureau (Gong'anbu). While in urban centres across China, the institution of marriage is undergoing 'deinstitutionalisation' (Davis and Friedman 2014), the room for the legitimate social and intimate relations in the border area is narrowing.

There is no easily discernible explanation as to why the Chinese local government changed its attitude towards unregistered marriages in the two Yao villages, having tolerated and accepted this phenomenon before. Neither the villagers nor the state representatives could give a straightforward answer. Growing tensions in bilateral relations over maritime space do not provide a satisfactory explanation, because the relationship between China and Vietnam has been unstable and fraught with mutual suspicion. It seems that a number of intersecting processes contribute to the closing off of the ambiguous non-state space of 'Zomia' with its overlapping and segmented claims to authority and accelerated institutionalisation of the state border and its bifurcated and rigid forms of distinctions. In order to expose these changes, I zoom out the focus of the micro-study of ethnic marriages on the Sino-Vietnamese border to consider the dynamics at the national, regional, and global levels. In particular, I consider the policy-shaping discourses on marriage migration in Asia and their influence in China, the impact of discourses on immigration and 'population security' in China, and the formulation and implementation of the global anti-human trafficking campaign in the Mekong region as important factors contributing to the new geopolitical reality. These discursive practices set the conditions and lay the grounds for how the changing sovereign bordering logic redefines the earlier customary practices as illegal.

\section{Discourses on Marriage Migration in East Asia}

Marriage migration is on rise globally, but particularly in East Asia - between, mostly, male citizens of South Korea, Japan, Taiwan, Singapore, and increasingly the PRC, and women

\footnotetext{
${ }^{8}$ According to the 2010 population census, female immigrants constituted about $43 \%$ or 257,578 of the total number of migrants in China (Shen 2012: 8).
} 
from Vietnam, North Korea, Myanmar, Laos, Indonesia and the Philippines (Constable 2005, Yang and Lu 2010, Williams 2010, Jones 2012). Governments in the region have used marriage migration regulations as a governing practice to re-examine their citizenship regimes (Toyota 2008) and a novel tool of border control (Friedman 2010). In South Korea the government response to the social problem of low birth rate and an aging society in the 1990s was a government-sponsored initiative to arrange marriage between Korean men and ethnic Korean women from China (Freeman 2011, LeeAn 2013). In other countries in the region marriage migration did not take the form of government-supported programme, but has been shaped by the commercial and broker services, which became a defining feature of both migration and marriage trends (Yeoh, Leng, Dung 2013: 45, Belanger, Lee, and Wand 2010).

With a growing number of marriage migrants, Asian state and public discourses have constructed 'foreign brides' as a social problem, associated with 'fake marriage, real prostitution' and 'the deterioriating quality of the next generation' (Hsia 2009: 29; Yang and Lu 2010: 42). In certain cases the government concern for the quality of the next generation led to the provision of subsidies for contraception for marriage migrants (Yang and Lu 2010: 42). Official statistics and surveys about foreign marriage migrants further lock them inside the patriarchal order of the family and the state, failing to recognize them as citizens. Across the region there is a certain public anxiety over the national commitments of migrant spouses (Friedman 2014: 286). In South Korea due to 'security' issues, migrants from Mainland China are treated as a separate category from other foreigners who are often grouped together and face stricter access to citizenship (Belanger, Lee, and Wang 2010: 1113). In Taiwan, marriage practices redefine the parameters of citizenship regime. Compulsory marriage interviews with Mainland Chinese spouses there work 'as a border practice regulating the aspired model of gendered family roles as the basis for nationhood' (Friedman 2010: 176). This shows how intimacy and individual marriage and migration choices became focal to border security concerns of the state in Asia and the centrality of the 'foreign brides' discourses in this process.

This detour into the discourses on 'foreign brides' in East Asia is important to bear in mind to understand the changing status of ethnic marriages on China's Southeast borders for several reasons. Firstly, the commercially-arranged marriages between Chinese men and foreign women from poorer countries in the region are a growing trend in China. With the 
declining availability and affordability of Chinese women, Chinese bachelors turn their gazes to the brides across the borders (Feng and Lan 2014). Secondly, 'commercially arranged' and ethnic marriages are viewed through the same lens of 'foreign brides'. Although there are significant differences in the patterns and living experiences of cross-border and transnational mail-order marriages (Nguyễn 2014: 94), Chinese scholars and policy makers look to other Asian countries' policies and public debates on 'foreign brides' in search for a solution of the 'illegal cross-border marriages' in China (Wang 2010, Huang and Chen 2011: 85-86). The language of commodification and illegality provides an analytical framework for viewing all cross-border marriages, including ethnic marriages in China (Ma 2012). A similar process of political re-framing of the local practice of 'elopement marriage tradition' through the national discourse on women trafficking and the target of anti-trafficking campaign in the late 1980s and 1990s was observed and reported by Chao (2005) in Yunnan province. And finally, as elsewhere in Asia, marriage migration is perceived in terms of border stability. The cross-border marriages are seen as posing a threat to China's security, as 'not favourable to the harmony and stability of the border' (Huang and Cheng 2011: 85). And the successful 'solution' of the cross-border marriage migration issue has been identified to be of pertinent importance to ensuring 'ethnic unity, social harmony and border stability' (Wang 2010: 98). In an environment where cultural identity is regarded to be an inalienable component of state security at the highest level of power in China ( $\mathrm{Hu} 2012$ ), ambiguous national status and identity of the ethnic marriage partners is a source of national security concern.

In the two villages were we conducted research there were no instances of commercially arranged 'mail-order' marriages, all marriages were the result of family and kinship links, where the priority for men is to marry a Yao woman. Yet, because ethnic marriage partners came from Vietnam, the largest source of 'mail-order' brides to China, they are all referred to as 'foreign' (waiji) or Vietnamese brides, and the women internalise this category of identification too. They refer to themselves as Vietnamese brides although 'foreign' and 'migrant' categories are misnomers to their experiences of ethnic marriage because they operate within a different non-state registers. A cross-border category is imposed on this type of marriages as the only available one, and their perception is limited to the state-centric political imagination. The discursive construction of the 'foreign bride' as an object of border controlling mechanism is an important element of modern migration management in China, as elsewhere, where disciplinary techniques are at play in shaping the 
migrant subject. The widespread perception of the ethnic marriage partners as 'illegal migrants' reflects a particular worldview conveyed by the Chinese state apparatus where a documented and sedentary lifestyle is a norm, and those without a document is an abnormality. And those who transgress the borders of accepted normality become 'illegal'. In our villages most marriages took place before the completion of the land border in 2001 which the border stones in the area mark. Although the women knew that the Yao men they were marrying with were from China, the border had been an abstract and distant construct for them, and only became prominently felt in the mid-2000s. When we asked two women if they knew where the border between China and Vietnam was, their answer was 'they knew' with the vague reference to the state authorities and border patrol. They observed that in the eyes of the state authorities, they appear as Vietnamese rather than Yao, and their new (illegal) status is due to the fact that they come from the wrong side of the border, although they and local men do not see any difference between Yao from the villages on the Chinese and Vietnamese sides of the border. New manifestations of sovereign border politics annihilated earlier existing marital practices rendering them illegal.

\section{Immigration and 'Population Security' in China}

The wider political debates on immigration and population security are relevant and important to consider as a regulatory context for the illegalisation of ethnic marriages in the border areas. Growing immigration to China has become a new catalyst of social change. With the increasing presence of foreign residents, new security implications for Chinese society have become more prominently expressed at the policy and scholarly levels. Chinese academics interpret the immigration/security nexus and other countries' experiences in managing immigration for the Chinese political elite (Tian 2010). As one Chinese scholar notes, the increased mobility across the borders created the problem of 'illegal' migration (Zhou 2004: 8). Chinese policy-makers take notice of the immigration dynamics as an important trend shaping China's economy and society (Xinhua 2010). In recognition of the increasing presence and role of foreign labour, residents, and immigrants in Chinese society, the 6th national census in 2010 for the first time included information on the number of 
foreigners living in China. ${ }^{9}$ In 2012 the first comprehensive Immigration Law came into force in the PRC replacing the 1994 Entry/Exit Regulation. As a result, immigration and population security are increasingly intertwined in the scholarly discussions and official pronouncements with reference to China's 'population security', in particular its aspects of 'population quantity' and 'population quality' (Luo 2012). 'Population quantity' primarily relates to the control of the population growth, and family planning, while the population 'quality' (renkou suzhi) is a notion which stresses eugenic aspects of the Chinese population as a whole, its levels of education, mannered behaviour and general 'civility', often measured against the presupposed Western parameters of modernity (Luo 2012: 115; Chen, Liu Cai, and Ji 2005; Qin 2003; Zhang 2004).

Since family planning was introduced in 1979 and birth-growth quota followed the suit in 1980, controlling population quantity has become China's main biopolitical concern. ${ }^{10}$ Population control remains one of the main priorities of the Chinese state, and the local governments of areas where the population growth quota is exceeded face steep fines. Chinese scholars increasingly draw attention to the paradoxical and controversial effects of the 'one-child policy' and traditional preference for boys in rural China. Chinese scholars estimate that the country's ratio of men to women are 117:100, and in the countryside they are as high as 132:100 ( $\mathrm{Li}$ and Long 2008b: 77). The sex ratio is becoming increasingly disproportionate, which drives the demand for women for Chinese singletons from outside China. Since 1995 every year in China about one million women go 'missing' and it is projected that by 2020 about 40 million foreign women will be required for Chinese single men (Zhang 2013: 213). 'Foreign brides' (waiji xinniang) are seen by some as a 'natural' corrective and a potential solution to the increasing shortage of women in China (Hou 2012: 61). There is a growing tension between the recognition of 'foreign brides' as a positive corrective to the skewed 'population quantity' in China and their negative association with 'low quality', weak social attachments, and unclear national identity.

\footnotetext{
${ }^{9}$ The number of foreigners, excluding Hong Kong, Taiwan and Macao, was estimated to be 593,832 (Shen 2012: 8). Other estimations give the figure of 1,020,000 foreign residents (Zhu and Price 2012: 4). It is likely that the census significantly underreported the actual number of foreigners residing in China.

${ }^{10}$ For an example of state rhetoric on this issue see 'The decision of the State Council and Chinese Communist Party Central Committee concerning overall strengthening of the population and family planning policy to solve the population problem', 17 December 2006, http://www.gov.cn/gongbao/content/2007/content 534194.htm (accessed 2 February 2014)
} 
During the fieldwork it became apparent that one of the main concerns associated with undocumented ethnic marriages is the birth of 'illegal babies' as a result of such liaisons. In the words of one Chinese scholar, marriage migrants create a headache for the local government's population control policy because they 'undermine' China's population security (Zhang 2009: 216). The women we talked with about the 2007 events described that that year there were increased acts of forced abortions and sterilisations of women who already had given birth to two children. They recounted the stories of the women who attempted to escape their ordeal in the family planning clinic by sliding down the drainage pipes. Such harrowing measures were not restricted to the border area alone. In 2007 in response to the local authorities' violent implementations of family planning policy in other parts of Guangxi region, riots broke out which informed the events described by novelist $\mathrm{Ma}$ Jian in his book The Dark Road (Ma 2010). The loss of sovereignty of their own bodies is the plight of many women in China, but those who are regarded as 'Vietnamese brides' pay the double price, as they are also subjected to the illegal status in China.

Running in parallel to the 'population quantity' debates, are the Chinese state's concerns regarding the 'population quality'. Academic and policy-oriented publications in China refer to udocumented marriage migrants as undermining the 'quality' of the Chinese population, because the majority of these people are poorly educated (Luo 2012: 116, Li and Long 2008b, Zhang 2009; 214). They deem them backward because they do not recognise the importance of official documents - 'feasting and drinking is enough for them to celebrate the wedding' (Zhang 2009: 214). The women's undocumented status and dubious state identity is said to cause problems for their and their children's 'socialisation' into the Chinese society (Gu 2009: 9). Some Chinese authors go as far as to conclude that such marriages cause 'fragmentation of Chinese identity' (cuipianhua), because of their strong links to Vietnam, prominent ethnic identity, and loose affiliation to Chinese identity. In China the forging of state identity among ethnic minorities living in proximity to a 'foreign society', and prone to be 'corroded' (qinshi) by 'outside influences', is perceived to be a primary measure of strengthening their affiliation with the Chinese state (Li and Long 2008b: 80). Li Xueyan and Long Yi (2008b) in their research on undocumented marriage migrants in Guangxi argue that the success of the Vietnamese brides' political and social integration could be measured by their political loyalty to the Chinese state. The fact that they share the same ethnic identity and language with their Chinese spouses does not seem to be taken into consideration. In 
China, where one of the written expectations from a Chinese citizen is 'love for the country and love for the party' (Hou 2012: 63), loose, fluid, and multiple affiliations are problematic to accept. The state-centric approach to border security and national identity perceives an expression of non-state identities or disinterest in national identity as a problem. The arguments of border security ignore the fact that local people's livelihoods and ethnic networks preceded the establishment of the international border in the area. The common ethnic marriage partners literally embody the contradictions in the sovereign state bordering logic imposed on the earlier existing governing practices.

The final process which I consider in this analysis is the formulation of anti-human trafficking regime in the Southeast Asia. As one of the central agenda-setting paradigms of border control in the region, the anti-human trafficking discourse contributes to shaping the dominant perception of undocumented ethnic marriages and their production of illegality.

\section{The slippery language of human trafficking}

In February 2010 Vietnam, as part of its programme to crack down on human trafficking announced that China was the main destination for trafficked children and women from Vietnam, constituting 65 per cent of all the investigated cases between 2004 and 2010 (Cheng 2010: 51). Guangxi and Yunnan, China's two gateways to the Southeast Asia, are coined as the main transit zones for human smugglers and traffickers (Huang and Chen 2011: 82). China has been recognizing the problem of domestic and international human trafficking, and addressed it in numerous state regulations and policies since the late 1980s (Sun and Li 2006: 36). A particularly active anti-human trafficking regime has been in making since 2002, when China and ten ASEAN countries signed the 'Framework Agreement on Comprehensive Economic Co-Operation between ASEAN and the PRC'. Since the Memorandum of Understanding on Cooperation against Trafficking in the Greater Mekong Sub-Region' between Mekong states (Vietnam, Thailand, Myanmar, PRC, Laos, Cambodia) was signed in Yangon on October 24 2004, a new regional initiative to devise a Sub-Regional Plan of Action Against Trafficking in Persons Between 2005-2007 was formulated (COMMIT 2007). As part of this initiative, new measures 'of action against trafficking in persons in all its forms', and 'adopting and enforcing, as quickly as possible, appropriate legislation against trafficking in persons' were proposed (COMMIT 2007: 57). 
Chinese publications identify two 'human trafficking channels' in China - trafficking for 'illegal marriage' and 'forced prostitution' (Sun and Li 2006: 28; Chen 2010: 51). Trafficking and illegal border-crossing are seen as two sides of the same coin, and the category of 'fake marriage' (pian hun) features prominently there (Chen 2010: 51; Gu 2009: 8). Some publications refer to common and illegal marriages interchangeably 'as traffic of illegal common marriages' (Wang 2010: 96). The 'illegal' family environment is seen as conducive to making children get involved with 'smuggling, drug dealing, and human trafficking' (Wang 2010: 96).

Human trafficking has been identified as a notoriously slippery phenomenon to define and research (Peet 2014). 'Trafficked persons' are hidden, and often do not view themselves as trafficked. Statistics on human trafficking are based on 'anecdotal' rather than empirical evidence (Ali 2005, Peet 2014). The human trafficking narratives at the heart of the international regulatory regime on human trafficking obscure and simplify the actual practices taking place. In the specific context of China's Southeastern border, they do not capture the complexity and local histories, practices and the women's life trajectories and choices (Grillot 2013: 159-160). The discourse on trafficking redefines people, practices, and groups in particular ways through the logic of victim/perpetrator and legal/illegal practices. The binary logic inherent in anti-trafficking regulations and campaign fails to capture the ambiguity involved in many border crossing practices.

In the Chima's border areas local governments showed more leniency towards longresiding Vietnamese women living with Chinese men, however, widespread repatriations take place. According to scholarly estimations, between 1995 and 2005 China repatriated 63,000 'illegal immigrants' (Zhu and Price 2012: 15). In many cases it was common for women that were 'sent back in the morning to come back in the evening' (Tan 2012). Some Chinese scholars note the ineffectiveness and futility of repatriation as a measure to address the issue (Chen 2010). In the case of the two Yao villages the local authorities, under the pressure of finding a solution to the problem, took the measure of making women more vulnerable to repatriation and investigations into 'human trafficking', because all cases of 'illegal entry, illegal residence, and illegal cohabitation' (feifa rujing, feifa juliu, feifa tonghun) are automatically considered suspect of human trafficking and Chinese media regularly reports 
on anti-human trafficking operations in the area. ${ }^{11}$ While there were no instances of repatriation in the villages since 2007, the women live in constant fear of being sent back to Vietnam as they are 'nobody in the eyes of the state, and they can get rid of us any moment if they wish to do so'. Anti-human trafficking measures serve as a convenient institutional channel to control unwanted migrants. In recent years China and Vietnam have actively collaborated on the joint implementation of anti-human trafficking regulations in the area, but there have been no bilateral efforts to find a mutual solution to recognizing the problems encountered by cross-border undocumented ethnic marriages or simplify the registration procedure for such marriages.

The dominant discourse on 'illegal marriage' as a channel for human trafficking and the widespread use of 'three illegals' category creates the reality of human trafficking on the Sino-Vietnamese border. The power of deciding whether a marriage or someone's status is legal or not does not lie with an individual, her family, and the local community, but with the state. Such framing of the issue erases the space for undocumented ethnic marriages to be recognized as valid, lasting, true social units and casts doubt on the voluntary character of the marriage because of its 'illegal' nature. The binary logic imposed by anti-human trafficking discourse together with the state sovereign formulations of the population security, and a growing influence of the 'Vietnamese bride' concept expresses the desire to strictly control cross-border mobility and organize it in a way compatible with the sovereign state logic. 'Illegal' marriages do not challenge state sovereignty in the same way common ethnic marriages do as they create an illusion of impermeable and indisputable nature of the sovereign border which only 'illegal' practices can violate.

\section{Conclusion}

This article considered how regional, national, and global bordering processes intertwine in complex ways to change the status of ethnic marriages at the Sino-Vietnamese border. It

\footnotetext{
${ }^{11}$ For examples of local media coverage of anti-trafficking operations in the Sino-Vietnamese border area in Guangxi see, 'Guangxi police rescue twenty six Vietnamese women in the round the clock operation', China Eastday, 18 August 2005, http://china.eastday.com/eastday/news/node37955/node37957/node37979/node80512/userobject1ai1359713.html (accessed 15 December 2014), 'Police from Pingxiang in Guangxi and Vietnam join forces in fighting transnational crime', China Anti-Smuggling Net, 11 August 2008 , http://www.jisi.gov.cn/News/szsm/gx/200808/20080811163133 273.html (accessed 15 December 2014), 'Pingxiang approves preventative programme of transnational trafficking in children and women and anti-trafficking model', Guangxi News, 26 April 2010 , http://www.gxnews.com.cn/staticpages/20060904/newgx44fb344d-804308.shtml (accessed 15 December 2014).
} 
highlighted how the delimitation of sovereign space and promotion of the border as an absolute and natural line marking sovereign territory, national imaginary, and citizenship rights laid the foundations for illegality for those who ambiguously relate to the rigidly defined state borders. The non-state geopolitical history and knowledge are increasingly giving way to the bi-national regime of borderland recasting earlier existing forms of knowledge, social organisation and identities along the bounded notions of ethnic groups, states and societies. Materialisation of the state border encapsulating the monopolization of the legitimate means of border-crossing brings into tension the contradictions between state definition of legality and existing local norms and practices. Along the materialisation of the bi-national border with its clear distinctions between inside and outside, the long existing local practices become refashioned as 'illegal'. With the proliferation of these developments, alternative non-state 'border imaginaries' (Vaughan-Williams 2008) are rendered illegitimate. The fiction of 'inside/outside' of global politics (Walker 1993) has become the reality of family lives on China's Southeast Asian borders.

In order to offer a greater understanding of the shift from 'common' ethnic to 'illegal' marriages, the discussion situated this development within a wider context of the accelerated closure of the non-state space and overlapping identities into the bi-national borderland and its bifurcated forms of categorisation. In particular, I drew attention not to the binary nature of the material border manifested in land marks and documentation per se, but to the overlapping context-setting processes which each contribute to redefining the status of ethnic marriages. The analysis thus highlights multidirectional and multidimensional nature of bordering practices. I suggested that the policy-shaping discourses on 'foreign brides' in Asia, the popularisation of 'population security' in the context of increased immigration to China, and the regional formulations of the global anti-human trafficking discourse and measures contribute to the institutional framing of undocumented ethnic marriages as illegal. Beyond the particular context of the Sino-Vietnamese border, the developments discussed in this article show how the proliferation of state borders penetrates the realm of family, the most intimate of social relates. State borders are not only spatially diffused, moving in and out of their territorial location, they disrupt the distinctions between private and public, conditioning the intimate life of families where the 'private body' is indistinguishable from the 'body politic' (Agamben 2000: 139). The reach of border practices to the realm of family relations, 
where state regulations encounter intimate life shows the deep reach and wide scope of sovereign power and how marital and sovereign decisions are intimately interwoven.

\section{References}

Agamben, Giorgio. (2000) Means without End: Notes on Politics. Minneapolis: University of Minnesota Press.

Agnew, John. (1994) The Territorial Trap: The Geographical Assumptions of International Relations Theory. Review of International Political Economy 1(1): 53-80.

Agnew, John. (2007) Know-Where: Geographies of Knowledge of World Politics. International Political Sociology (1)2: 138-148.

Alberts, Eli. (2006) A History of Daoism and the Yao People of South China. New York: Cambria Press.

Ali, A. K. M. Masud. (2005) Treading along a Treacherous Trail: Research on Trafficking in Persons in South Asia. International Migration 43(1/2): 141-164.

Alvarez, Robert. R. (1995) The Mexican-U.S. Border: The Making of an Anthropology of Borderland. Annual Review of Anthropology 24: 447-470.

Andreas, Peter. (2000) Border Games: Policing the US-Mexico Divide. Ithaca, NY: Cornell University Press.

Belanger, Daniele, Hye-Kyung Lee and Hong-Zen Wang. (2010) Ethnic Diversity and Statistics in East Asia: 'Foreign brides' surveys in Taiwan and South Korea. Ethnic and Racial Studies 33(6): 1108-1130.

Chan, Yuk Wah. (2013) Vietnamese-Chinese Relationships at the Borderlands: Trade, Tourism, and Cultural Politics. London: Routledge.

Chao, Emily. (2005) Cautinary Tales; Marriage Strategies, State Discourse, and Women's Agency in a Naxi Village in Southwestern China. In Cross-Border Marriages: Gender and Mobility in Transnational Asia, edited by Nicole Constable. Philadelphia: University of Pennsylvania Press.

Chen, Gong, Liu, Jufen, Cai Chunguang, and Ji Ying. (2005) Security and Population Security: Development and Discussion of the Concept. Market and Demographic Analysis 11(2): 1-11.

Chen, Xi. (2010) Research on the Sino-Vietnamese Trafficking Problem. Journal of Wuhan Public Security Cadre's College 92 (4).

Cheng Zong. (2010) Research on Women Trafficking in the Sino-Vietnamese border. The Journal of Wuhan Institute of Security Cadres 92(4): 51-52.

CNN (2009) Report: China, Vietnam Agree on Land Border. 1 January, http://edition.cnn.com/2009/WORLD/asiapcf/01/01/china.vietnam/index.html (accessed 20 May 2014). 
Constable, Nicole. (ed.) (2005) Cross-Border Marriages: Gender and Mobility in Transnational Asia. Philadelphia: University of Pennsylvania Press.

'The COMMIT Sub-Regional Plan of Action (COMMIT SPA): Achievements in Combating Human Trafficking in the Greater Mekong Sub-Region, 2005-2007', 2007, http://www.no-trafficking.org/reports_docs/commit/commit_spa1_achievements.pdf, (accessed 3 February 2014).

Davis, Deborah, and Friedman, Sara L. (eds.) (2014) Wives, Husbands, and Lovers: Marriage and Sexuality in Hong Kong, Taiwan, and Urban China. Stanford: Stanford University Press.

Donnan, Hastings and Thomas Wilson. (2010) Ethnography, Security and the 'Frontier Effect' in Borderlands. In Borderlands: Ethnographic Approaches to Security, Power, and Identity, edited by Hastings Donnan and Thomas Wilson. Lanham: University Press of America, pp.

Du, Chengxiu. (2014) Analysis of the approach towards legalisation of Sino-Vietnamese illegal marriages, Guangxi Social Studies, 12 April, http://www.scimao.com/read/82563\#floor_reply, accessed 15 December 2014.

Feng Shijun and Lan Feng. (2014) A New Wave of Foreign Brides Buying: Are These Marriages Reliable? Women's Life 5: 4-6.

Ferradas, Carmen A. (2010) Security and Ethnography on the Triple Frontier of the Southern Cone. In Borderlands: Ethnographic Approaches to Security, Power, and Identity, edited by Hastings Donnan and Thomas Wilson. Lanham: University Press of America.

Flynn, Donna K. (1997) 'We are the Border': Identity, Exchange, and the State along the Benin-Nigeria Border. American Ethnologist 24(2): 311-330.

Freeman, Caren. (2011) Making and Faking Kinship: Marriage and Labor Migration between China and South Korea. Ithaca and London: Cornell University Press.

Friedman, Sara L. (2010) Determing 'Truth' at the Border: Immigration Interviews, Chinese Marital Migrants, and Taiwan's Sovereignty Dilemmas, Citizenship Studies 14(2); $167-$ 183.

Friedman, Sara L. (2014) Marital Borders: Gender Population, and Sovereignty across the Taiwan Strait. In Wives, Husbands, and Lovers: Marriage and Sexuality in Hong Kong, Taiwan, and Urban China, edited by Deborah S. Davis and Sara L. Friedman. Stanford: Stanford University Press.

Galemba, Rebecca B. (2013) Illegality and Invisibility at Margins and Borders. PoLAR: Political and Legal Anthropology Review 36(2): 274-285.

Giersch, Charles P. (2006) Asian Borderlands: The Transformation of Qing China's Yunnan Frontier. Cambridge: Harvard University Press.

Grillot, Caroline. (2013) The Fringes of Conjugality: On Fantasies, Tactics and Representations of Sino-Vietnamese Encounters in Borderlands, unpublished $\mathrm{PhD}$ Thesis, Vrije Universiteit Amsterdam.

Gu, Jiarong. (2009) Place, Status, Identity: Analysis of Dai Cross-Border Marriages in Jishuihe village in Yunnan. Nationalities Research in Qinghai 20(4): 5-9. 
Hou, Xinhua. (2012) Analysis of Foreign Marriages among Baoshan Border Dwellers, and Issues of Social Stability. The Journal of Baoshan Institute, 59-63.

Hsia, Hsiao-Chuan. (2009) Foreign Brides, Multiple Citizenship and Immigrant Movement in Taiwan. Asia and the Pacific Migration Journal, Vol.18, Issue 1: 17-46.

Hu, Jintao. (2012) Resolutely Walk the Path of Socialist Culture Development with Chinese Characteristics: Striving to Construct a Strong Socialist Culture Country. Qiushi 1(1).

Huang, Hefei and Chen, Suhao. (2011) An Analysis of Sino-Vietnamese Cross-border Marriages - an Example of one County in Guangxi. Around Southeast Asia 8: 82-86.

Jeffreys, Elaine and Wang, Pan. (2013) The Rise of Chinese-foreign Marriage in Mainland China, 1979-2010. China Information 27(3): 347-369.

Jiang, Dechui. (2012) The Analysis of Sino-Vietnamese Cross Border Marriage Legal Issues. Rule of Law Viewpoint 20: 120-121.

Johnson, Corey; Jones, Reece; Paasi, Anssi; Amoore, Louise; Mountz, Alison; Salter, Mark; Rumford, Chris. (2011) Interventions on Rethinking 'the Border' in Border Studies. Political Geography 30: 61-69.

Jones, Gavin W. (2012) International Marriage in Asia: What Do We Know, and What do We Need to Know? Asia Research Institute Working Paper Series No 174, January 2012, www.ari.nus.edu.sg/docs/wps/wps12_174.pdf (accessed 20 May 2014).

Keyes, Charles. (2002) Presidential Address: 'The Peoples of Asia' - Science and Politics in the Classification of Ethnic Groups in Thailand, China, and Vietnam. The Journal of Asian Studies 61(4): 1163-1203.

Lee, Hye-Kyung. (2008) International Marriage and the State in South Korea: Focusing on Governmental Policy. Citizenship Studies 12(1): 107-123.

LeeAn, Jiyoung. (2013) Negotiating Citizenship: a Case Study of Marriage Migration between South Korea and Vietnam, a conference paper presented at ICAS 7, Macau.

Liang, Maochun and Chen, Wen. (2014) Transnational Undocumented Marriages in the SinoVietnamese Border Areas of China. Asian and Pacific Migration Journal 23(1): 113 125.

Li Xueyan and Long Yao. (2008a) Research on the Sino-Vietnamese Cross-border Marriages (the focus on children): the Case of Ai village Guangxi Daxin County. World Ethnicity 5: 77-85.

Li Xueyan and Long Yao. (2008b) Research on the Sino-Vietnamese Cross-border Marriages (the focus on women): the Case of Ai Village Guangxi Daxin County. World Ethnicity 4: 75-80.

Litzinger, Ralph A. (1995) Making Histories: Contending Conceptions of the Yao Past. In Cultural Encounters on China's Ethnic Frontiers, edited by Stevan Harrell. Seattle and London: University of Washington Press.

Liu, Qiufen. (1986) Analysis of the Current Situation of Vietnamese Female Marriage Migration. Around Southeast Asia: 15-17. 
Luo, Gang. (2012) Effects of Illegal Immigrants on the Population Security and National Identity: A Case Study of the Minority Areas in the Borderland of Yunnan. Yunnan Normal University Studies: Philosophy and Social Sciences Edition 44(4): 114-120.

Luo, Liuning. (2010) Analysis of the Social Foundations of Transnational Marriages in the Sino-Vietnamese Border - the Focus on the Identity of Stateless Women. Guangxi Minority Research 1: 57-61.

Ma, Liping. (2012) On the Problem of Illegal Transnational Marriage Migration along Yunnan-Vietnamese border from the Perspective of Migration Sociology. Journal of Honghe University 10(1): 19-23.

Mignolo, Walter. (2011) The Darker Side of Western Modernity: Global Futures, Decolonial Options. Durham and London: Duke University Press.

Nguyễn, Thi Phuong Cham. (2014) Cross-Border Brides: Vietnamese Wives, Chinese Husbands in a Border-Area Fishing Village. Cross-Currents: East Asian History and Culture Review 11: 92-117.

Ong, Aihwa. (2000) Flexible Citizenship: The Cultural Logics of Transnationality. Durham: Duke University Press.

Oxfeld, Ellen. (2005) Cross-Border Hypergamy? Marriage Exchanges in a Transnational Hakka Community. In Cross-Border Marriages: Gender and Mobility in Transnational Asia, edited by Nicole Constable.Philadelphia: University of Pennsylvania Press.

Peet, Jessica. (2014) Agentless Victims or Victimized Agents: Dominant Narratives of Human Trafficking, a conference paper presented at the 2014 International Studies Association Convention, Toronto.

Qin, Sheng. (2003) The Summary of World Population Security Issues. International Data and Information 12.

Reeves, Madeleine. (2014) Border Work: Spatial Lives of the State in Rural Central Asia. Ithaca and London: Cornell University Press.

Scott, James. (2009) The Art of Not Being Governed: An Anarchist History of Upland Southeast Asia. Hew Heaven and London: Yale University Press.

Shen Haimei. (2012) Understanding China's 'Foreign Brides' in the Framework of Transnational Migration Theory. Journal of Kunming University of Science and Technology 12(5): 6-13.

Soguk, Nevzat. (2007) Border's Capture: Insurrectional Politics, Border-Crossing Humans, and the New Political. In Borderscapes: Hidden Geographies and Politics at Territory's Edge, edited by Prem Kumar Rajaram and Carl Grundy-Warr. Minneapolis: University of Minnesota Press.

Sowerwine, Jennifer. (2013) Socialist Rules and Postwar Politics: Reflections on Nationality and Fieldwork among the Yao in Northern Vietnam. In Red Stamps and Gold Stars: Fieldwork Dilemmas in Upland Socialist Asia, edited by Sarah Turner. Vancouver: The University of British Columbia. 
Sun, Xiaoying and Li, Bihua. (2006) Research Report on Anti-Women and Child Trafficking. Around Southeast Asia 12: 28-39.

Tan, Wanping. (2012) The Analysis of the Social-Legal Studies of Sino-Vietnamese CrossBorder Marriages. Journal of Yunnan University Law Edition 25(1): 178-182.

ter Haar, Barendt. (1998) A New Interpretation of the Yao Charters. In New Developments in Asian Studies, edited by Paul van der Velde and Alex McKay. London: Kegan Paul International.

Tian, Yuan. (2010) Migration and State Security: the Sources and Conditions of Threat. Beijing: World Knowledge Publishers.

Torpey, John C (2000) The Invention of the Passport: Surveillance, Citizenship, and the State. Cambridge: Cambridge University Pres.

Toyota, Mika. (2005) Subjects of the Nation Without Citizenship: the Case of 'Hill Tribes' in Thailand. In Multiculturalism in Asia, edited by Will Kymlicka and Baogang He. Oxford: Oxford University Press.

Toyota, Mika. (2008) Editorial Introduction: International Marriage, Rights and the State in the East and Southeast Asia. Citizenship Studies 12(1): 1-7.

Vaughan-Williams, Nick. (2008) Border, Territory, Law. International Political Sociology 2(4): $322-338$.

Walker, Rob B.J. (1993) Inside/Outside: International Relations as Political Theory. Cambridge: Cambridge University Press.

Wang, Hui and Huang, Jiaxin. (2007) Women Without Nationality: a Group Wandering Between Tradition and Modernity. Journal of Baise University 20(1): 1-6.

Wang Xiaodan. (2010) The Effects of the Sino-Vietnamese Cross-border Marriages on the Social Development of Yunnan's Border. The Journal of Chuxiong Normal University 25(2): 96-99.

Wang Xiaodan. (2011) The Dynamics and Effects of Cross-border Marriages - an Example of Malipo County in Yunnan. Yunnan Normal University Journal: Philosophy and Sociology Edition 43(1): 117-120.

Wendl, Tobias and Michael Rösler. (eds.) (1999) Frontiers and Borderlands: Anthrpological Perspectives. Frankfurt am Main: Lang.

Williams, Lucy. (2010) Global Marriage: Cross-border Marriage Migration in Global Context. Palgrave Macmillan.

Wilson, Thomas M and Hastings Donnan. (1998) eds., Border Identities: Nation and State at International Frontiers. Cambridge: Cambridge University Press.

Winichakul, Thongchai. (1994) Siam Mapped: A History of the Geo-Body of a Nation. Honolulu: University of Hawaii Press. 
Xinhua News Agency. (2010) China Plans Draft Immigration Law, 22 May, http://www.chinadaily.com.cn/china/2010-05/22/content_9881622.htm (accessed 12 February 2014).

Yang, Wen-Shan and Melody Chia-Wen Lu. (eds.) (2010) Asian Cross-border Marriage Migration: Demographic Patterns and Social Issues. Amsterdam: Amsterdam University Press.

Yeoh, Brenda S. A, Chee Heng Leng and Vu Thi Kieu Dung. (2013) Commercially Arranged Marriage and the Negotiation of Citizenship Rights among Vietnamese Marriage Migrants in Multiracial Singapore. Asian Ethnicity 14(2): 139-156.

Zhang Jie. (2009) Illegal Cross-border Marriage Migration and Sino-Vietnamese Border Security - a Case of Guangxi's Border Region. Academy of Social Science International Research Anthology: 209-218.

Zhang, Mincai. (2004) Population Security and Construction of Moderately Prosperous Society. Population and Economy 6.

Zhou, Guanghua. (2004) The Features of Population Security. Population and Family Planning 2: 8-9.

Zhou, Jianxin. (2002) Sino-Vietnamese and Sino-Lao Cross-border Ethnic groups and Ethnic Relations. Beijing: Ethnic Press.

Zhu, Guobin and Price, Rohan. (2012) Chinese Immigration Law and Policy: A Case of 'Change Your Direction, or End Up Where You are Heading.' Columbia Journal of Asian Law, 21 June, http://ssrn.com/abstract=2088683 (accessed 10 January 2014).

Zhuang, Huining. (2012) How Many Foreigners are Exactly in 'Three Kinds of Illegal Situations?' People's Public Security 5: 24.

Ma Jian (2013) 'China's Barbaric One-child Policy', the Guardian, http://www.theguardian.com/books/2013/may/06/chinas-barbaric-one-child-policy, accessed 20 January 2015. 